\title{
Pawet Letko
}

Uniwersytet Warmińsko-Mazurski w Olsztynie

\section{STOSUNKI RADZIECKO-MAROKAŃSKIE W KONTEKŚCIE RYWALIZACJI ZIMNOWOJENNEJ W ŚWIETLE ŹRÓDEŁ RADZIECKICH I AMERYKAŃSKICH}

Przedmiotem niniejszego szkicu jest prezentacja stosunków radziecko-marokańskich w aspekcie politycznym, gospodarczym i wojskowym. Ramy czasowe wyznaczają lata 1958 (oficjalne nawiązanie stosunków dyplomatycznych) oraz 1989 (ostatnie spotkanie na wysokim szczeblu), choć Maroko znalazło się w orbicie zainteresowań radzieckich pod koniec II wojny światowej, w związku z funkcjonowaniem Międzynarodowej Strefy Tangeru (powołanej w 1923 r.). Celem rozważań jest przedstawienie rozwoju współpracy między ZSRR i Marokiem, jej głównych założeń i efektów. W ujęciu chronologicznym omówione zostaną wizyty dyplomatyczne, podpisywane porozumienia i wystąpienia przedstawicieli obu państw na forum międzynarodowym. Opisywane fakty dają podstawę do wnioskowania na temat wagi, jaką Moskwa i Rabat przykładały do stosunków dwustronnych. Ważnym kontekstem są, z jednej strony, stosunki Maroka z USA i innymi państwami Zachodu, z drugiej zaś - współpraca ZSRR z Algierią.

Międzynarodowa Strefa Tangeru, w czasie wojny przyłączona do hiszpańskiego Maroka, została przekazana administracji Komisji Międzynarodowej, w skład której wchodziły: Belgia, Holandia, Hiszpania, Francja, Portugalia i Wielka Brytania. W 1945 r. pojawił się projekt, by do Komisji przyłączyły się także Stany Zjednoczone i Związek Radziecki. W dniach 10-31 sierpnia 1945 r. w Paryżu z udziałem ZSRR odbyła się konferencja w sprawie przyszłości Tangeru. Przyjęty wówczas Akt Końcowy zakładał, że Moskwa i Waszyngton będą współuczestniczyć w administrowaniu tego obszaru. Ostatecznie ZSRR zrezygnował z członkostwa w Komisji, motywując to m.in. niechęcią do podważania integralności Maroka czy współpracy z frankistowską Hiszpanią ${ }^{1}$.

W następnych latach ZSRR dyplomatycznie wspierał marokańskie dążenia do niepodległości, zwłaszcza na forum ONZ. Podczas siódmej sesji Zgroma-

\footnotetext{
${ }^{1}$ G.H. Stuart, The International City of Tangier, Stanford University Press 1955, s. 33, 149-165.
} 
dzenia Ogólnego ONZ w 1952 r. radziecki przedstawiciel w Pierwszej Komisji oświadczył, że Moskwa wspiera aspiracje Marokańczyków do pełnej niepodległości. Także podczas kolejnych sesji przedstawiciele Maroka mogli liczyć na życzliwość ZSRR, dzięki czemu łatwiej było przyjąć korzystne dla nich rezolucje $^{2}$. Na XIX zjeździe WKP(b) w 1952 r. m.in. za to poparcie dziękował w iście wiernopoddańczym stylu przedstawiciel Marokańskiej Partii Komunistycznej (MPK) Ali Yata ${ }^{3}$.

Już po formalnym uzyskaniu niepodległości ZSRR wsparł Rabat w związku z sytuacją Tangeru. 5 lipca 1956 r. Maroko podpisało protokół z Komisją Międzynarodową potwierdzający zasadę integralności kraju i likwidację Strefy Tangeru, nie wyznaczono jednak konkretnego terminu. W dniach 8-19 października 1956 r. odbyła się konferencja międzynarodowa w Fedali (obecnie Al-Muhammadijja) z udziałem państw reprezentowanych w Komisji Międzynarodowej zarządzającej Strefą. 9 października 1956 r. Moskwa wydała oświadczenie, w którym wyraziła nadzieję, że konferencja doprowadzi do jak najszybszego zjednoczenia Maroka z Tangerem. Spotkanie zakończyło się przyjęciem deklaracji, w której zgodzono się na zniesienie międzynarodowej kontroli nad Strefą i ustalono datę przekazania jej pod kontrolę Maroka na 1 stycznia 1957 r. Moskwa nie kryła zadowolenia i 11 grudnia potwierdziła pełnię praw Rabatu do Tangeru oraz uznała za nieważne wszystkie wcześniejsze umowy międzynarodowe dotyczące tego miasta ${ }^{4}$.

Trzy miesiące po proklamowaniu niepodległości przez Maroko, 11 czerwca 1956 r., ZSRR uznał marokańskie władze i wyraził gotowość nawiązania stosunków dyplomatycznych. Jak poinformował amerykańskiego ambasadora Cavendisha Cannona minister spraw zagranicznych Ahmed Balafrej, do września 1956 r. Moskwa trzykrotnie wyraziła zainteresowanie nawiązaniem stosunków dyplomatycznych. Amerykanie starali się wpływać na odroczenie tej decyzji, ale zdawali sobie sprawę, że nie mogą wywierać zbytniego nacisku, aby nie urazić Rabatu. Ograniczono się jedynie do wskazywania, że intencje ZSRR „budzą podejrzenia”, ponieważ wcześniej Moskwa nie była zbyt zainteresowana sprawami Maroka, a nawiązanie stosunków dyplomatycznych w momencie, gdy nie ma ważnych powodów, by to czynić, może niepotrzebnie skomplikować sytuację wewnętrzną oraz stosunki z Zachodem, który jest zainteresowany stabilnym rozwojem krajus . Ostatecznie dwa i pół roku po odzyskaniu nie-

${ }^{2}$ E.A. Tarabrin, USSR and Countries of Africa, Moscow 1970, s. 95-96.

${ }^{3}$ ХІХ съезд ВКП(б) - КПСС (5-14 октября 1952 года). Аокументы и материальь, Москва 2013, s. 123.

${ }^{4}$ СССР и арабские страны, 1917-1960: документы и материалы, Москва 1961, s. 228, 287-288; В. Аурденевский, К ликвидации зоны Танжера, „МежАународная жизнь” 1957, № 1; J.A.C. Gutteridge, The Dissolution of the International Régime in Tangier, „British Year Book of International Law” 1957, Vol. 33 , s. 298-302.

5 Telegram from the Department of State to the Embassy in Morocco, Washington, September 23, 1956, Foreign Relations of the United States (dalej: FRUS), 1955-1957, Vol. XVIII: Africa, ed. S. Shaloff, Washington 1989, s. 540-541. 
podległości przez Maroko, 1 września 1958 r., nastąpiło formalne nawiązanie stosunków dyplomatycznych. Pierwszym rosyjskim ambasadorem w Maroku mianowano Dmitrija Pietrowicza Pożydajewa, który pełnił swoją misję od 11 października 1958 r. do 20 lipca 1962 r.

19 kwietnia 1958 r. została podpisana pierwsza umowa handlowa - Moskwa w zamian za pomarańcze, konserwy rybne, wełnę i korę drzewa korkowego zobowiązała się dostarczać ropę naftową, maszyny i tarcicę. Jednocześnie podpisano porozumienie o udzieleniu przez ZSRR kredytu w wysokości $500 \mathrm{mln}$ franków ${ }^{6}$. W 1958 r. do Maroka dotarł pierwszy transport radzieckiej broni, dostarczonej za pośrednictwem Czechosłowacji ${ }^{7}$.

Mimo że obydwa kraje reprezentowały bardzo różne systemy politycznogospodarcze, nie przeszkadzało im to w utrzymywaniu dobrych kontaktów. Nie wpływało na nie także kilkukrotne delegalizowanie MPK (i jej następczyni), uznającej przywództwo ZSRR, oraz represjonowanie jej członków. We wrześniu 1959 r., kiedy zdelegalizowano MPK, podpisano roczną umowę handlową na dostarczanie przez ZSRR m.in. ropy naftowej i produktów naftowych, tarcicy, maszyn i urządzeń w zamian za skóry, wełnę, owoce cytrusowe i migdały ${ }^{8}$. Miesiąc wcześniej, w obliczu kryzysu finansowego, Maroko, chcąc zmniejszyć finansową presję Paryża, sondowało możliwość wyjścia ze strefy franka.

Według raportów CIA Moskwa chciała wykorzystać ten fakt, oferując nieoprocentowaną pożyczkę w wysokości $100 \mathrm{mln}$ dolarów. Wzbudziło to zaniepokojenie Waszyngtonu, który obawiał się wzmocnienia w ten sposób wpływów radzieckich? .

Związek Radziecki zdobył sobie wdzięczność Maroka, blokując w 1960 r. przystąpienie Mauretanii do ONZ. Niewątpliwie było to także zasługą syna króla Muhammada V - Hassana, stojącego na czele delegacji marokańskiej do Zgromadzenia Ogólnego ONZ. Jego spotkanie z Chruszczowem jesienią 1960 r. w Nowym Jorku, życzliwa postawa wobec Chin, Konga czy Kuby musiały pozytywnie wpłynąć na stosunki dwustronne. Wprawdzie w następnym roku Moskwa wycofała swój sprzeciw, ale zrealizowane wówczas dostawy radzieckiej broni wzmocniły marokańską armię. Dobre stosunki Maroka z ZSRR stały się metodą na zmiękczanie stanowiska Francji i USA wobec Rabatu, rząd marokański wykorzystywał także tę współpracę jako argument do zwalczania

${ }^{6}$ A Calendar of Soviet Treaties 1958-1973, ed. G. Ginsburg, R. Slusser, Alphen aan der Rijn 1981, s. 12.

${ }^{7}$ Memorandum from the Acting Secretary of State to the President, Washington, September 22, 1959, FRUS, 1958-1960, Vol. XIII: Arab-Israeli Dispute; United Arab Republic; North Africa, ed. S.E. Coffman, Ch.S. Sampson, Washington 1992, s. 789.

${ }^{8}$ A Calendar..., s. 69.

${ }^{9}$ Memorandum of Discussion at the 417th Meeting of the National Security Council, Washington, August 18, 1959, FRUS, 1958-1960..., s. 785-786. 
wewnętrznej lewicowej krytyki. Moskwa zaś miała nadzieję na osłabienie wpływów Zachodu na kontynencie afrykańskim ${ }^{10}$.

W listopadzie 1960 r. do Moskwy przybyła marokańska delegacja przyjaźni i dobrej woli z byłym premierem Ahmedem Balafrejem na czele. W tym samym miesiącu radziecki rząd zobowiązał się przekazać do Maroka myśliwce odrzutowe, a 10 lutego następnego roku okręt „Karaganda” dostarczył 12 (według innych źródeł 20) samolotów MiG-17F i 2 MiG-15UTI. Rabat zgodził się na to mimo ostrych protestów USA. Zdaniem amerykańskich polityków, radziecka obecność w Maroku mogłaby zagrażać bezpieczeństwu baz amerykańskich w tym kraju, a ponadto bazom w Hiszpanii, VI Flocie oraz całej południowej flance NATO. Waszyngton nieco się uspokoił po zapewnieniach króla, że wraz ze sprzętem nie pojawi się personel z ZSRR, a piloci będą szkolić się w Zjednoczonej Republice Arabskiej lub w innym miejscu, aby uniknąć bezpośredniej zależności od Moskwy. Ambasador Charles Yost przestrzegał jednak, że stanowisko to może ulec zmianie. Amerykanie nie byli do końca pewni intencji Muhammada V i w następnych tygodniach temat potencjalnej obecności radzieckich techników w Maroku był dość często poruszany podczas rozmów dyplomatycznych; łączono go z kwestią dostarczenia amerykańskiej pomocy militarnej. W kontekście radzieckiej obecności w Maroku pojawił się także temat baz amerykańskich, które wcześniej czy później miały zostać opuszczone. Waszyngton starał się uzyskać od króla zapewnienie, że nie zostaną one przekazane w użytkowanie innym państwom, zwłaszcza ZSRR ${ }^{11}$. W następnych miesiącach okazało się, że zapewnieniom Marokańczyków nie można ufać - wraz z MiG-ami przypłynęli także radzieccy specjaliści ${ }^{12}$. Dostawa samolotów miała być pierwszym etapem programu radzieckiej pomocy wojskowej dla Maroka. Zgoda na przyjęcie radzieckich samolotów podyktowana była, jak się wydaje, chęcią wywarcia nacisku na Waszyngton, aby kontynuował dozbrajanie marokańskiej armii, co w kolejnych latach udało się osiągnać.

Mimo współpracy amerykańsko-marokańskiej w dziedzinie uzbrojenia ZSRR próbował zwiększyć dostawy swojego sprzętu. Pod koniec 1961 r. Moskwa złożyła nową ofertę - marokański minister obrony udał się do ZSRR, aby ją przedyskutować. Według amerykańskich informacji efektem była umowa,

${ }^{10}$ S. Touval, The Boundary Politics of Independent Africa, Harvard University Press 1999, s. 128; Political Leaders of the Contemporary Middle East and North Africa. A Biographical Dictionary, ed. B. Reich, Greenwood Press 1990, s. 223.

${ }^{11}$ E. Hinterhoff, The Pattern of Soviet Military Aid, „The Tablet”, November 24, 1962, s. 1127; Memorandum of a Conversation, Pentagon, Washington, December 21, 1960, FRUS, 1958-1960..., s. 814-815; Telegram from the Department of State to the Embassy in Morocco, Washington, February 18, 1961, FRUS, 1961-1963, Vol. XXI: Africa, ed. N.D. Howland, Washington 1995, s. 162-164; Memorandum from Secretary of State Rusk to President Kennedy, Washington, February 24, 1961, FRUS, 1961-1963..., s. 165-166.

12 Telegram from the Department of State to the Embassy in Morocco, Washington, May 26, 1961, FRUS, $1961-1963 \ldots$... s. 175-176. 
w której ZSRR zobowiązał się dostarczyć broń strzelecką, artylerię i czołgi wartości 3-4 mln dolarów ${ }^{13}$.

W dniu dostarczenia radzieckich samolotów dwudniową nieoficjalną wizytę w Maroku rozpoczął Przewodniczący Prezydium Rady Najwyższej Związku Radzieckiego Leonid Breżniew, odpowiedzialny za kompleks wojskowo-przemysłowy, który spotkał się m.in. z królem Muhammadem V. Podczas rozmów dotyczących współpracy gospodarczej i kulturalnej radziecki polityk potwierdził chęć udzielenia pomocy niezbędnej do rozwoju i industrializacji afrykańskiego państwa ${ }^{14}$.

Po śmierci Muhammada V (26 lutego 1961 r.) na tron wstąpił jego syn - Hassan II. Początkowo współpraca radziecko-marokańska układała się poprawnie. Nowy monarcha dążył do budowy dużej stoczni i nowoczesnego centrum szkolenia morskiego w rejonie Tangeru. O pomoc w realizacji projektu poprosił Moskwę. W grudniu 1961 r. do Casablanki, na koszt ZSRR, przybyła trzyosobowa delegacja z przedstawicielem Państwowego Komitetu ds. Przemysłu Stoczniowego Nikołajem Czerniajewem na czele. W styczniu 1962 r. do Maroka przybył wicepremier Anastas Mikojan, który w towarzystwie radzieckich specjalistów rozmawiał z królem, ministrem gospodarki i gubernatorem Tangeru. Hassan II mówił o ambitnych planach uprzemysłowienia kraju i wyraził nadzieję na zaangażowanie ZSRR. Planowana stocznia miała być konkurencją dla hiszpańskich enklaw Ceuta i Melilla. Ostatecznie projekt, którego koszt szacowano na 15 mld starych franków, ze względu na trudności polityczne i gospodarcze oraz francuskie wpływy, nie został zrealizowany (do dziś w regionie Tangeru nie ma dużej stoczni) ${ }^{15}$.

12 maja 1962 r. radziecki rząd przyjął postanowienie o dostawach broni i sprzętu wojskowego do Maroka. W tym samym roku marokańska armia została wzmocniona czołgami T-54 ${ }^{16}$.

${ }^{13}$ Memorandum from Robert W. Komer of the National Security Council Staff to President Kennedy, Washington, January 5, 1962, FRUS, 1961-1963..., s. 197; Memorandum from Robert W. Komer of the National Security Council Staff to the President's Special Assistant for National Security Affairs (Bundy), Washington, January 29, 1962, FRUS, 1961-1963..., s. 199-200; Memorandum from Acting Secretary of State Ball to President Kennedy, Washington, March 15, 1962, FRUS, 1961-1963..., s. 202-203; Memorandum from Robert W. Komer of the National Security Council Staff to President Kennedy, Washington, April 4, 1962, FRUS, 1961-1963..., s. 204-205.

${ }^{14}$ R. Nyrop et al., Area Handbook for Morocco, Washington 1972, s. 211; Aperçu sur les relations entre le Maroc et la Russie, s. 3, http://www.ambmaroc.ru/imagsite/Conf.sur\%20les\%20relations\%20maroco-russes\%20mai\%20 09.doc [dostęp 14.12.2014]; А. Розин, Африканские эпизоды советского флота - Марокко, http://alerozin.narod. ru/MoroccoSovietNavy.htm [dostęp 14.12.2014]; Квизиту Президента РФ Владимира Путина в Марокко, „Компас” ИТАР-ТАСС 2006, № 36, s. 22, http://www.library.mephi.ru/data/Semi/2006/kompas/N36_ s21-28.pdf [dostęp 14.12.2014].

${ }^{15}$ В. Чуров, Белье пятна истории: СССР и Марокко, „Вести ФМ”, 16.04.2013, http://radiovesti. ru/audio/161/167.mp3 [dostęp 7.12.2014]; Aperçu sur..., s. 3.

${ }^{16}$ A. Розин, ор. cit.; G.D. Ra'anan, The Evolution of the Soviet Use of Surrogates in Military Relations with the Third World, with Particular Emphasis on Cuban Participation in Africa, "The Rand Paper Series” 
Czasowe ochłodzenie stosunków nastąpiło pod koniec 1963 r. - 14 października doszło do wybuchu wojny marokańsko-algierskiej o sporne tereny przygraniczne. Związek Radziecki opowiedział się po stronie Algierii, wzmacniając ją nawet dostawami broni, choć w trosce o stosunki z Rabatem sprzęt dostarczono na statkach kubańskich. W ciągu dwóch lat po zakończeniu walk już oficjalnie ZSRR przekazał Algierii m.in. około $30 \mathrm{MiG-ów} \mathrm{i} 150$ czołgów. Znajdujące się w Maroku radzieckie samoloty nie zostały natomiast użyte w czasie walk (załogi nie były jeszcze dostatecznie wyszkolone). Mimo że w następnych latach stosunki radziecko-marokańskie poprawiły się, współpraca wojskowa w zasadzie zamarła. W latach 1967-1968 dotarły jeszcze transporty czołgów T-54 (za pośrednictwem Czechosłowacji), ale król Hassan II, nie chcąc zadrażniać stosunków z USA, zrezygnował w 1967 r. z większości zaplanowanych dostaw czechosłowackiej i radzieckiej broni oraz samolotów transportowych ${ }^{17}$. Samoloty dostarczone w 1960 r., pozbawione części zamiennych i obsługi technicznej, zostały unieruchomione, a na początku lat 80 . XX w. pocięte na złom ${ }^{18}$.

Hassan II, chcąc zwiększyć rolę swojego kraju wśród państw arabskich i afrykańskich, w połowie lat 60 . zaczął realizować politykę opartą na wielostronnych kontaktach. U jej podstaw znalazł się trójkąt Francja-USA-ZSRR. Nie miał on charakteru „równobocznego”, ponieważ Rabat wyraźnie ciążył w kierunku państw zachodnich, jednak współpraca z ZSRR miała częściowo zrównoważać wpływy zachodnie i wzmocnić autorytet międzynarodowy Maroka.

Jesienią 1966 r. do Moskwy z oficjalną, choć kilkakrotnie odkładaną wizytą przybył Hassan II (wizytę króla przygotowywał przebywający w Moskwie w dniach 18-22 lipca minister spraw zagranicznych Ahmed Laraki ${ }^{19}$ ). Monarcha spotkał się z wieloma prominentnymi politykami, m.in. z Breżniewem. 27 października podpisano pięć porozumień dotyczących współpracy w dziedzinie gospodarczej (m.in. w sprawie kredytu w wysokości $32 \mathrm{mln}$ rubli), naukowo-technicznej, kulturalnej, radiofonii i telewizji oraz o dostawach maszyn i urządzeń do Maroka. Następnego dnia wydano wspólny komunikat, w którym strony wyraziły zadowolenie z dotychczasowej współpracy ${ }^{20}$. Mimo gościnnego przyjęcia Hassan II nie miał wątpliwości (przynajmniej w rozmowach z amerykańskimi dyplomatami), że Moskwa najchętniej pozbawiłaby go korony i zastąpiła lewicowym rządem. Niepokoiła go także ścisła współpraca wojskowa między Algierią i ZSRR ${ }^{21}$.

P-6420 (December 1979), s. 8-9, http://www.rand.org/content/dam/rand/pubs/papers/2005/P6420. pdf [dostęp 14.12.2014]; E. Hinterhoff, op. cit., s. 1127.

${ }^{17}$ Telegram from the Embassy in Morocco to the Department of State, Rabat, August 5, 1967, FRUS, 1964-1968, Vol. XXIV: Africa, ed. N.D. Howland, Washington 1995, s. 211.

${ }^{18}$ А. Розин, op. cit.; G.D. Ra’anan, op. cit., s. 9-10.

${ }^{19}$ A Calendar..., s. 358.

${ }^{20}$ Ibidem, s. 336; Memorandum from the President's Special Assistant (Rostow) to President Johnson, Washington, July 19, 1966, FRUS, 1964-1968..., s. 183.

${ }^{21}$ Memorandum of Conversation, Washington, January 25, 1967, FRUS, 1964-1968..., s. 188-190; Paper Prepared by the Ambassador at Large (Harriman), Washington, undated, FRUS, 1964-1968..., s. 187-188. 
Aby zbyt mocno nie drażnić Stanów Zjednoczonych, Hassan II na początku 1967 r. udał się do Waszyngtonu. 9 lutego doszło do spotkania z prezydentem Johnem F. Kennedy'm. Król ponownie wyraził zaniepokojenie zagrożeniem ze strony Algierii, dozbrajanej przez ZSRR. Breżeniew, z którym rozmawiał na ten temat kilka miesięcy wcześniej, miał jedynie ogólnikowo stwierdzić, że Moskwa nie chciałaby, aby Maroko uwikłało się w konflikty z przyjaciółmi ZSRR, wymieniając wśród nich Algierię. Dlatego też Hassan II podczas spotkania z amerykańskim prezydentem poprosił o pomoc, a Kennedy obiecał kredyt w wysokości 14 mln dolarów, za które miała być dostarczona broń (głównie samoloty myśliwskie) ${ }^{22}$. Realizacja umowy przedłużała się jednak w czasie. Administracja amerykańska niechętnie odnosiła się do tego pomysłu, obawiając się eskalacji wyścigu zbrojeń w Afryce Północnej i na Bliskim Wschodzie, podejrzewając jednocześnie, że informacje o planowanej przez Algierię agresji mają jedynie doprowadzić do podjęcia przez Waszyngton decyzji korzystnych dla Maroka ${ }^{23}$.

Inaczej sprawę widzieli wojskowi. Przewodniczący Kolegium Połączonych Szefów Sztabów Earle G. Wheeler w czerwcu 1967 r., w memorandum skierowanym do sekretarza obrony Roberta S. McNamary, stwierdził, iż rząd amerykański powinien pozytywnie odpowiedzieć na prośby Rabatu, bo w przeciwnym razie mogą się wzmocnić podejrzenia świata arabskiego, że USA wspiera tylko Izrael, ponadto amerykańska armia mogłaby utracić dostęp do obiektów na terytorium Maroka (np. stacji łączności marynarki wojennej w Kenitrze) ${ }^{24}$. 5 czerwca 1968 r. na biurko kolejnego prezydenta, Lyndona B. Johnsona trafiło memorandum, w którym przypomniano o obietnicach Kennedy'ego oraz zwrócono uwagę, że jeżeli Waszyngton nie dostarczy obiecanych F-5, to Rosjanie są gotowi sprzedać swoje MiG-21. Następnego dnia ambasada w Rabacie otrzymała telegram, w którym polecono rozpocząć negocjacje w związku z kredytem w wysokości 14 mln dolarów ${ }^{25}$.

Marokańczycy nie zamierzali przy tym rezygnować z profitów ze współpracy z ZSRR. W lutym 1967 r. w Casablance otwarto drugie radzieckie przedstawicielstwo w Maroku - konsulat generalny. W 1968 r. Hassan II zgodził się na legalizację Partii Wyzwolenia i Socjalizmu z Ali Yatą na czele, która była oficjalną reprezentacją komunistów w Maroku. Mimo że została ona rozwiązana w następnym roku, nie przeszkodziło to rozwojowi stosunków marokań-

\footnotetext{
${ }^{22}$ Memorandum of Conversation, Washington, February 9, 1967, FRUS, 1964-1968..., s. 197.

${ }^{23}$ Telegram from the Department of State to the Embassy in Morocco, Washington, June 17, 1967, FRUS, $1964-1968 \ldots$.., s. 204-205.

${ }^{24}$ Memorandum from the Joint Chiefs of Staff to Secretary of Defense McNamara, Washington, June 21, 1967, FRUS, 1964-1968..., s. 205-206.

${ }^{25}$ Memorandum from the President's Special Assistant (Rostow) to President Johnson, Washington, June 5, 1968, FRUS, 1964-1968..., s. 217-218.
} 
sko-radzieckich. Od 1 do 7 kwietnia 1969 r. w Rabacie przebywał z rewizytą przewodniczący Prezydium Rady Najwyższej ZSRR Nikołaj Podgorny, oczekiwany z niecierpliwością (liczono na radziecką pomoc w realizacji planu pięcioletniego, co faktycznie udało się uzyskać). Jednym z efektów wizyty było powołanie w sierpniu tego roku Radziecko-Marokańskiej Komisji Międzyrządowej ds. Współpracy Gospodarczej i Naukowo-Technicznej. Wizyta miała dla króla Hassana II dość nieoczekiwany skutek, ponieważ został usunięty z listy gości zaproszonych do Waszyngtonu ${ }^{26}$.

Jesienią 1971 r. do Maroka z oficjalną wizytą przybył premier Aleksiej Kosygin. 10 października popisano umowę dotyczącą żeglugi morskiej oraz wydano wspólny komunikat, w którym obie strony odnotowały zbieżność poglądów w wielu kwestiach międzynarodowych, a także uzgodniły konieczność okresowych konsultacji. Wypowiedziano się ponadto za intensyfikacją współpracy, a przedstawiciel ZSRR zapowiedział dalszą pomoc gospodarczą i techniczną. $\mathrm{Na}$ początku 1973 r. do Moskwy zawitała marokańska delegacja z ministrem spraw zagranicznych Ahmedem Taibiem Benhimą na czele, aby wziąć udział w posiedzeniu Radziecko-Marokańskiej Komisji Międzyrządowej. Oficjalnie tematem rozmów miał być marokański eksport do ZSRR oraz pomoc w realizacji marokańskiego planu pięcioletniego. Efektem był wydany 27 stycznia komunikat, w którym strona marokańska pozytywnie oceniła radzieckie inicjatywy pokojowe, a Moskwa okazała aprobatę dla polityki niezaangażowania prowadzonej przez Rabat ${ }^{27}$. Benhima miał wówczas także poprosić o części zamienne i amunicję do sprzętu radzieckiego będącego już w posiadaniu Marokańczyków oraz o nowy lekki sprzęt wojskowy. Gdy na początku lutego do Rabatu przyleciał mały radziecki samolot transportowy z dwudziestoma osobami na pokładzie, Amerykanie podejrzewali, że są to członkowie radzieckiej misji wojskowej, którzy mieli zająć się rozmowami w tej sprawie ${ }^{28}$.

Pod koniec marca 1973 r. w Moskwie odbyło się kolejne posiedzenie Radziecko-Marokańskiej Komisji Międzyrządowej; na czele delegacji marokańskiej stał minister handlu, przemysłu, górnictwa i marynarki handlowej Abdelkaber Benslimane. Po zakończeniu obrad agencja informacyjna Nowosti poinformowała, że zawarto porozumienia dotyczące budowy kompleksów hydroenerge-

${ }^{26}$ Telegram 2481 from the Embassy in Morocco to the Department of State, May 18, 1969, FRUS, 1969-1976, Vol. E-5, Part 2, Documents on North Africa, 1969-1972, ed. M.L. Belmonte, Washington 2007, http:// history.state.gov/historicaldocuments/frus1969-76ve05p2/d98 [dostęp 14.12.2014]; Intelligence Note 195 from the Director of the Bureau of Intelligence and Research (Hughes) to Secretary of State Rogers, Washington, March 19, 1969, FRUS, 1969-1976, Vol. E-5..., http://history.state.gov/historicaldocuments/frus196976ve05p2/d1 [dostęp 7.12.2014].

${ }^{27}$ Primin's Moscow Talks Inconclusive, 27.02.1976, http://wlstorage.net/oc/2082/7511.pdf [dostęp 5.12.2014].

${ }^{28}$ Soviet Military Mission in Rabat, 9.03.1973, http://wlstorage.net/oc/2472/120135.pdf [dostęp 14.12.2014]. 
tycznych, badań geologicznych, poszukiwań ropy naftowej i gazu ziemnego oraz zagospodarowania złóż fosforanów ${ }^{29}$.

Jednocześnie już 29 stycznia tego samego roku Hassan II zaproponował Amerykanom, by Benhima po powrocie z Moskwy jak najszybciej spotkał się z sekretarzem stanu Williamem P. Rogersem ${ }^{30}$. Na początku kwietnia doszło do wizyty ministra w Waszyngtonie, gdzie przyjął go zastępca sekretarza stanu ds. afrykańskich David D. Newsom; rozmawiano wówczas m.in. o wzmocnieniu współpracy amerykańsko-marokańskiej w obszarach gospodarki i wojskowości, tłumaczono (na polecenie króla), że współpraca z Moskwą w dziedzinie wojskowej nie jest przejawem zmiany kursu polityki zagranicznej Rabatu, a jedynie wynika z pragmatyzmu - Maroko potrzebuje nowego sprzętu (w tym lekkich czołgów) w przystępnych cenach, aby poprawić zdolność swojej armii do szybkiego reagowania ${ }^{31}$.

Następne tygodnie pokazały, że Moskwa nie zrezygnowała ze zwiększenia swojej obecności w Maroku. Gdy w lutym Hassan II zdecydował o wysłaniu trzytysięcznego kontyngentu do Syrii, miał problemy z przetransportowaniem żołnierzy i sprzętu. W kwietniu Rosjanie zaoferowali udostępnienie własnych statków. Najprawdopodobniej w związku z przygotowaniami do przeprowadzenia akcji 19 kwietnia w Oranie pojawił się minister żeglugi morskiej Timofiej Gużenko. Ponadto do bazy lotniczej w Meknes przybył 35-osobowy zespół radzieckiego personelu lotniczego, który według Amerykanów miał pomóc w organizacji transportów drogą powietrzną. Wzrost zainteresowania Marokiem potwierdziła również zmiana na stanowisku attaché wojskowego w Rabacie - 23 kwietnia oficera w stopniu pułkownika zastąpił generał ${ }^{32}$. W lipcu Rosjanie mieli udostępnić dwa kolejne okręty do transportu drugiego rzutu sił marokańskich do Syrii - co ciekawe, większość obydwu kontyngentów była wyposażona w radziecką broń ${ }^{33}$. Dla Moskwy jednak przez cały czas w regionie ważniejsza była Algieria, do której nieprzerwanym potokiem płynął strumień sprzętu i doradców. Hassan II zdawał sobie sprawę z dysproporcji sił, dlatego

${ }^{29}$ Joint Soviet-Moroccan Commission Meetings in Moscow, 27.03.1973, http://wlstorage.net/oc/2472/ 3264.pdf [dostęp 7.12.2014]; Moroccan-Soviet Relations Entering New Phase, 12.05.1973, http://wlsto rage.net/oc/2472/20029.pdf [dostęp 7.12.2014].

${ }^{30}$ Letter from Robert Murphy to Secretary of State Rogers, Washington, February 1, 1973, FRUS, 1969-1976, Vol. E-9, Part 1, Documents on North Africa, 1973-1976, ed. M.F. Burton, Washington 2014, s. 161.

${ }^{31}$ Secretary Newsom and Foreign Minister Benhima Discuss US-Moroccan Relations, 12.04.1973, http:// wlstorage.net/oc/2472/15640.pdf [dostęp 14.12.2014]; Moroccan-Soviet Relations Entering New Phase...

${ }_{32}$ Moroccan Troops to Syria - Possible Soviet Assistance, 20.04.1973, http://wlstorage.net/oc/2472/12574.pdf [dostęp 14.12.2014]; Moroccan-Soviet Relations Entering New Phase...

${ }_{33}$ Draft Report to NATO Ministers on Mediterranean Situation, 19.11.1973, http://wlstorage.net/ oc/2472/93483.pdf [dostęp 13.12.2014]; Moroccan Marine Forces, 14.07.1976, http://wlstorage.net/ oc/2082/177740.pdf [dostęp 14.12.2014]. 
zabiegał o wzmocnienie zdolności obronnych kraju. Rozmawiał na ten temat w grudniu 1973 r. z ambasadorem USA Robertem G. Neumannem ${ }^{34}$.

W sierpniu 1974 r. Hassan II zgodził się na powstanie nowej partii politycznej - Partii Postępu i Socjalizmu, następczyni Partii Wyzwolenia i Socjalizmu, znów z Ali Yatą na czele. Wiązało się to z sytuacją wewnętrzną - król dążył do jak największego rozdrobnienia opozycji, a komuniści nie wydawali się ani liczni, ani groźni. Ponadto chciał on zyskać przychylność krajów bloku wschodniego i ZSRR, licząc na poparcie na forum ONZ w związku z sytuacją w Saharze Zachodniej. Moskwa dobrze zdawała sobie sprawę z tych uwarunkowań. Co ciekawe, podobnie oceniali sytuację Amerykanie i nie wyrażali swojego sprzeciwu. Sam Yata już od lutego 1972 r. uzyskał zgodę na wydawanie tygodnika „Al Bayane”, na którego łamach gorąco popierał ideę włączenia Sahary Zachodniej w granice Maroka ${ }^{35}$. W sierpniu 1974 r. udał się w podróż do Moskwy i stolic Europy Wschodniej (ale marokańska prasa pisała tylko o wizycie w Rumunii i Jugosławii), gdzie miał wysondować stanowisko Rosjan w sprawie Sahary Zachodniej. Po powrocie do Maroka stwierdził, że Moskwa podziela stanowisko Rabatu, uważając, iż przyznanie Saharze Zachodniej niepodległości doprowadzi do destabilizacji całego regionu i w związku z tym ma pewne zastrzeżenia do polityki algierskiej (popierającej aspiracje Polisario), ale nie może tego oficjalnie oświadczyć ze względu na własne interesy w Algierii ${ }^{36}$.

W styczniu 1975 r. w Moskwie miało miejsce kolejne spotkanie Radziecko-Marokańskiej Komisji Międzyrządowej. Stronę marokańską reprezentował minister handlu, przemysłu, górnictwa i marynarki handlowej Abdellatif Ghissassi. Tematem rozmów było m.in. wykorzystanie marokańskich złóż fosforanów czy łupków roponośnych ${ }^{37}$. Moskwa obiecywała znaczną pomoc w eksploatacji złoża w Meskala za $10 \mathrm{mln}$ ton fosforanów rocznie. Waszyngton obawiał się, że Maroko, które już było największym eksporterem fosforanów, jeszcze bardziej zdominuje rynek i w porozumieniu z Rosjanami może dyktować ceny, a oceniano, że USA jeszcze co najmniej przez 10 lat będzie zależne od marokańskich dostaw $^{38}$. Mimo że rozmowy radziecko-marokańskie szły początkowo

\footnotetext{
${ }^{34}$ Technical Advisory Team to Morocco, 12.12.1973, http://wlstorage.net/oc/2472/114599.pdf [dostęp 14.12.2014].

35 Morocco's Most Prominent Communist Forms New Party, 29.09.1974, http://wlstorage.net/oc/2474. 2/118121.pdf [dostęp 14.12.2014].

${ }^{36}$ Meeting with Communist Leader Ali Yata: Moscows View of Spanish Sahara, 10.10.1974, http://wlsto rage.net/oc/2474.2/151817.pdf [dostęp 12.12.2014].

${ }^{37}$ Ministerial Level GOM Team Visits Morocco to Discuss Minerals Exploitation, Foreign Assistance and Trade, 24.01.1975, http://wlstorage.net/oc/2476/8929.pdf [dostęp 14.12.2014].

${ }^{38}$ Morocco-Soviet Phosphate Talks Resume: Timing Us Justice Department Inquiries Inconvenient, 29.05.1975, http://wlstorage.net/oc/2476/82174.pdf [dostęp 12.12.2014].
} 
dość opornie, we wrześniu 1975 r. do Moskwy poleciała specjalna delegacja, aby sfinalizować porozumienie ${ }^{39}$.

W 1975 r. narastał kryzys wokół Sahary Zachodniej, zwłaszcza po „zielonym marszu” dochodziło do licznych napięć między Marokiem a Algierią. Moskwa, niespecjalnie zainteresowana poświęceniem dobrych stosunków z obydwoma krajami, starała się nie zajmować jednoznacznego stanowiska. Kosygin miał wówczas powiedzieć do rosyjskiego ambasadora w Maroku, że ZSRR oficjalnie popiera zasadę samostanowienia narodów, ale w sprawie Sahary stanowisko to „nie jest sztywne”. Na początku listopada Moskwę odwiedził minister Benhima. Wizyta nie przyniosła satysfakcjonujących Rabat wyników ${ }^{40}$. W następnych tygodniach pojawiły się jednak sygnały, które mogły napawać Hassana II pewnym optymizmem - Rosjanie przyczynili się do odrzucenia algierskiego wniosku, by Rada Bezpieczeństwa zajęła się problemem zachodniosaharyjskim, a następnie z okazji 20-lecia odzyskania niepodległości przez Maroko na falach „Radia Moskwa” mówiono o szacunku dla założeń marokańskiej polityki zagranicznej ${ }^{41}$. Także w Waszyngtonie nie chciano referendum w sprawie niepodległości Sahary Zachodniej. Przegrana Maroka byłaby wówczas pewna, a to osłabiłoby pozycję Hassana II, który z kwestii zachodniosaharyjskiej uczynił sprawę narodową ${ }^{42}$.

Mimo że ZSRR starał się nie angażować bezpośrednio w konflikt w Saharze Zachodniej, król Maroka w styczniu 1976 r. w rozmowach z ambasadorem Neumannem wyrażał zaniepokojenie co do intencji władz w Moskwie. Podczas spotkania z dowódcą VI Floty wiceadmirałem Frederickiem C. Turnerem interesował się danymi wywiadowczymi na temat ruchu radzieckich statków, stwierdził również, że wizyta amerykańskich okrętów podwodnych w marokańskich portach zawsze będzie mile widziana oraz ponowił prośbę o szybkie dostarczenie samolotów F-5. Amerykański dowódca skorzystał z okazji i uzyskał ustną zgodę na przeprowadzenie na marokańskim wybrzeżu ćwiczeń symulujących desant w celu zabezpieczenia ewakuacji ${ }^{43}$.

Rosjanie, widząc obniżający się poziom zaufania, zwłaszcza po zestrzeleniu marokańskiego samolotu przez żołnierzy Polisario, wykorzystujących radziecką

${ }^{39}$ Status Report: GOM/Soviet Phosphate Discussions, 23.09.1975, http://wlstorage.net/oc/2476/164135.pdf [dostęp 12.12.2014].

40 SovietPosition on Sahara, 10.11.1975, http://wlstorage.net/oc/2476/204167.pdf[dostęp 2.12.2014]; Chill Descends on Soviet-Moroccan Relations, 18.11.1975, http://wlstorage.net/oc/2476/204643.pdf [dostęp 12.12.2014].

${ }^{41}$ Sahara Roundup, 20.11.1975, http://wlstorage.net/oc/2476/204736.pdf [dostęp 14.12.2014]; Sahara Developments, 25.11.1975, http://wlstorage.net/oc/2476/204735.pdf [dostęp 14.12.2014].

${ }^{42}$ A. Kosidło, Sahara Zachodnia, Fiasko dekolonizacji czy sukces podboju. 1975-2011, Gdańsk 2012, s. 45.

${ }^{43}$ King Hassan's Comments on Sahara, 8.01.1976, http://wlstorage.net/oc/2082/59455.pdf [dostęp 7.12.2014]; King Hassan Receives Commander of Sixth Fleet, 23.01.1976, http://wlstorage.net/ oc/2082/59919.pdf [dostęp 7.12.2014]. 
broń, starali się przekonać Marokańczyków, że nie mają z tym nic wspólnego. Ambasador Dmitrij Gorunow pod koniec stycznia 1976 r. nie negował faktu użycia radzieckiej broni, ale zaprzeczał, że została dostarczona przez ZSRR czy też była obsługiwana przez radzieckich techników ${ }^{44}$.

$\mathrm{Na}$ początku 1976 r., powracający z oficjalnej wizyty w Japonii, premier Ahmed Osman niespodziewanie zawitał do Moskwy, gdzie 20 lutego spotkał się z Kosyginem. Rozmawiano o "przyjaznych stosunkach łączących obydwa kraje” oraz sytuacji w Saharze Zachodniej. Według doniesień o spotkanie poprosiła strona marokańska, która chciała wywrzeć presję na Algierię w związku z rosnącym napięciem wokół Sahary Zachodniej. Za sukces Rabatu można uznać, że Moskwa wyraziła niechęć wobec eskalacji konfliktu ${ }^{45}$.

Według amerykańskich ocen sprawa Sahary Zachodniej i wsparcia dla Frontu Polisario nie wpłynęła znacząco na relacje radziecko-marokańskie, a ZSRR starał się unikać bezpośredniego zaangażowania w konflikt, mając nadzieję, że zostanie on rozwiązany na drodze dyplomatycznej (chociaż w najbliższej przyszłości nie widziano takiej możliwości), aby nie nadwyrężać stosunków z Marokiem ${ }^{46}$. Być może była to błędna diagnoza - Osman nie rozmawiał w Moskwie na temat fosforanów (czym Rosjanie byli bardzo zainteresowani), a w maju 1976 r. miał powiedzieć, że w najbliższym czasie nie wybiera się do ZSRR, mimo iż został oficjalnie zaproszony przez Kosygina ${ }^{47}$. Z drugiej strony, radzieckie Tu-114 lecące na Kubę tankowały na lotnisku w Rabacie. Marokańczycy bez skutku próbowali ukryć to przed Amerykanami, którzy ze swej strony nie chcieli interweniować drogą oficjalną, a jedynie dali marokańskim urzędnikom do zrozumienia, że wiedzą, co się dzieje - ambasador Robert Anderson rozmawiał na ten temat z dowódcą królewskiej żandarmerii płk. Housnim Benslimane ${ }^{48}$.

Pod koniec 1976 r. pojawiły się oznaki pewnego ocieplenia w stosunkach radziecko-marokańskich. W połowie grudnia do Rabatu przybyła delegacja z ministrem geologii Jewgienijem Kozłowskim na czele. Kozłowski spotkał się z premierem Osmanem i ministrem Ghissassim. Na początku grudnia pojawiły się

${ }^{44}$ Soviets Seek to Placate GOM, Downplay Sahara Role, 28.01.1976, http://wlstorage.net/oc/2082/ 166021.pdf [dostęp 12.12.2014].

${ }^{45}$ Primin Osman Makes Surprise Stopover in Moscow, 23.02.1976, http://wlstorage.net/oc/2082/7559.pdf [dostęp 12.12.2014]; Primin's Moscow talks inconclusive...

${ }^{46}$ Action Memorandum from the Assistant Secretary of State for Near Eastern and South Asian Affairs (Atherton) to Secretary of State Kissinger, Washington, February 10, 1976, FRUS, 1969-1976, Vol. E-9..., s. 199; Soviet Official Discusses Sahara Dispute, 6.02.1976, http://wlstorage.net/oc/2082.2/344601.pdf [dostęp 12.12.2014].

${ }_{47}$ Current Soviet Attitude on Sahara, 11.05.1976, http://wlstorage.net/oc/2082/117920.pdf [dostęp 14.12.2014].

${ }^{48}$ Soviet Tu-114 Flights Through Rabat, 1.10.1976, http://wlstorage.net/oc/2082.2/265892.pdf [dostęp 7.12.2014]; Soviet Tu-114 Flights Through Rabat, 12.10.1976, http://wlstorage.net/oc/2082.2/265884. pdf [dostęp 7.12.2014]; Soviet Tu-114 Flights Through Rabat, 2.11.1976, http://wlstorage.net/oc/ 2082.2/293029.pdf [dostęp 12.12.2014]. 
informacje na temat przyjazdu radzieckiej misji wojskowej, która negocjowała warunki dostarczenia 120 czołgów T-62 oraz części zamiennych do już posiadanego radzieckiego sprzętu, ale porozumienia w tej sprawie nie osiągnięto. Została natomiast otwarta nowa linia obsługiwana przez Aerofłot, łącząca Moskwę z Gwineą Bissau, z międzylądowaniem w Casablance, a radzieccy specjaliści zaangażowali się w poszukiwania niklu i budowę małych portów na wybrzeżu $^{49}$. Z drugiej strony Hassan II w rozmowie z ambasadorem Andersonem w lutym 1977 r. niechętnie odnosił się do ekspansji radzieckiej w Afryce i na Bliskim Wschodzie, deklarując chęć aktywnego uczestnictwa w jej powstrzymywaniu i wspierania USA swoimi wpływami i doświadczeniem ${ }^{50}$. Praktyczną realizacją tych zamierzeń była decyzja z 8 kwietnia o wysłaniu marokańskich żołnierzy do Katangi w Zairze, gdzie walczących separatystów mieli wspierać doradcy kubańscy i radzieccy ${ }^{51}$. W wywiadzie udzielonym 18 kwietnia 1977 r. król po raz pierwszy publicznie wyraził wątpliwości wobec radzieckiego zaangażowania w Afryce ${ }^{52}$.

Nie przeszkodziło to kontynuowaniu rozmów w sprawie fosforanów. W maju 1977 r. w Moskwie przebywał Mohammed Karim Lamrani (dyrektor L'Office Chérifien des Phosphates zajmującej się wydobyciem i eksportem fosforanów), przygotowując ostateczną wersję porozumienia ${ }^{53}$. Umowę sfinalizował premier Osman, który w dniach 9-13 marca 1978 przebywał w ZSRR, tym razem z wizytą oficjalną. 10 marca wspólnie z Leonidem Breżniewem podpisał porozumienie o zaangażowaniu ZSRR w zagospodarowanie złóż w regionie Meskala, tym bardziej cennych, że zawierały także uran ${ }^{54}$. W 1980 r. w Moskwie był też minister spraw zagranicznych Mohammed Boucetta. 6 listopada podpisał następną umowę dotyczącą wydobycia fosforanów w Meskala - ZSRR miał udzielić 20 mln dolarów kredytu spłaconego fosforanami ${ }^{55}$. W roku 1982 w Moskwie gościł ponadto obecny król Maroka Muhammad VI, który, wówczas jako następca tronu, wziął udział w pogrzebie Breżniewa ${ }^{56}$.

\footnotetext{
${ }^{49}$ State of Soviet/Moroccan Relations, 7.07.1977, http://wlstorage.net/oc/oc/2532/4521.pdf [dostęp 2.12.2014].

${ }^{50}$ King Hassan's Views of Middle East and Soviet Threat, 15.02.1977, http://wlstorage.net/oc/oc/2532/ 36195.pdf [dostęp 12.12.2014].

${ }^{51}$ Morocco and the Zaire Intervention, 29.04.1977, http://wlstorage.net/oc/oc/2532/88844.pdf [dostęp 12.12.2014].

${ }^{52}$ King Hassan's April 18 Press Interview, 21.04.1977, http://wlstorage.net/oc/oc/2532/90476.pdf [dostęp 14.12.2014].

${ }^{53}$ MFA Official Discusses Mauritania, UN, OAU and SOVIET, 3.06.1977, http://wlstorage.net/oc/oc/ 2532/127004.pdf [dostęp 14.12.2014].

${ }_{54}^{4}$ Фильм Премьер-министр королевства Марокко в СССР... (1978), Режиссер К. Старокадомская, http://net-film.ru/film-8080/?search=p7\%7cy2; Maandoverzicht maart 1978, Ministerie van Defensie, s. 17, http://www.stichtingargus.nl/bvd/m/mo7803.pdf [dostęp 12.12.2014].

55 A. Saal, Chronologie des faits internationaux d'ordre juridique, „L'Annuaire français de droit international”, Vol. 26 (1980), s. 1030; K. Connor, The Mineral Industry of Morocco, „Minerals Yearbook area reports" 1981, Vol. 3, s. 687.

${ }^{56}$ Траурный митинг на Красной площади, „Правда” 1982, № 320, s. 2.
} 
W latach 80. politycy marokańscy przyjeżdżali do Moskwy jako przedstawiciele delegacji Ligi Państw Arabskich. W trakcie rozmów m.in. z sekretarzem generalnym Jurijem Andropowem, premierem Nikołajem Ryżkowem, ministrami spraw zagranicznych Andriejem Gromyko i Eduardem Szewardnadze dyskutowano na temat Bliskiego Wschodu (grudzień 198257) czy konfliktu iracko-irańskiego (kwiecień i wrzesień 1987). Do ostatniego spotkania na wysokim szczeblu doszło 29 czerwca 1989 r. - Michaił Gorbaczow spotkał się z ministrem spraw zagranicznych Abdellatifem Filali i rozmawiał z nim na temat Libanu ${ }^{58}$.

Radziecko-marokańska współpraca wojskowa z pewnością nie była tak intensywna, jak by sobie tego życzyła Moskwa. Mimo radzieckich zabiegów, większość broni docierała do Maroka z Zachodu. Również likwidacja w 1964 r. amerykańskich baz wojskowych nie przełożyła się na zwiększenie radzieckiej obecności. W zasadzie jedynym przykładem współpracy wojskowej były wizyty radzieckich okrętów wojennych. W latach 1968-1973 miało miejsce dziewięć takich wydarzeń (oficjalnych i roboczych) - najwięcej, bo aż sześć, w latach 1972-1973. Strona marokańska, traktując tego typu zdarzenia jako okazję do pokazania światu swojej niezależności, jednocześnie starała się bagatelizować ich znaczenie. Na przykład, podczas wizyty w październiku 1968 r. w Casablance pięciu okrętów płynących w kierunku Pacyfiku, przedstawiciele władz lokalnych i ludność dosyć serdecznie przyjęli Rosjan, ale władze regionalne i centralne, mimo że wizytę połączono z 10-leciem nawiązania stosunków dyplomatycznych, wydarzenie zignorowały. Także władze portowe wszelkimi sposobami starały się utrudniać wizyty Marokańczyków na okrętach, nie zgodzono się na propozycję zorganizowania występu artystycznego w centrum miasta czy wizyty uczniów miejscowych szkół na okrętach ${ }^{59}$.

Rosjanie kilkakrotnie jeszcze oferowali Marokańczykom swój sprzęt wojskowy. Oficerowie marokańscy w Syrii zapoznali się z czołgami T-62, po powrocie poinformowali, że zaoferowano im dostarczenie lepszych czołgów niż amerykańskie M48A3 i na lepszych warunkach. Dlatego król Hassan II w rozmowie z ambasadorem Neumannem w czerwcu 1974 r. stwierdził, że szybko potrzebuje czołgów M60, aby zmniejszyć niezadowolenie w armii ${ }^{60}$. W $1975 \mathrm{r}$. rozpoczęła się modernizacja marokańskiej marynarki wojennej. Rabat zamówił wówczas w większości okręty francuskie, ale podpisano także umowę na sześć radzieckich kutrów rakietowych Osa- $\mathrm{II}^{61}$.

\footnotetext{
${ }^{57}$ Справочник партийного работника, Выпуск 23, Москва 1983, s. 263-264.

${ }_{58}^{5}$ М.С. Горбачев, Собрание сочинений, Т. 15: Июнь-сентябрь 1989, Москва 2010, s. 60-62.

${ }^{59}$ А. Розин, ор. cit.

${ }^{60}$ Telegram 2565 from the Embassy in Morocco to the Department of State, Rabat, June 6, 1974, FRUS, 1969-1976, Vol. E-9..., s. 177.

${ }^{61}$ FY 1977 Military Security Assistance, 3.02.1976, http://wlstorage.net/oc/2082.2/333494.pdf [dostęp 12.12.2014].
} 
Współpraca Maroka z ZSRR wywoływała duże zaniepokojenie w Waszyngtonie. Zauważono, że konflikt między Rabatem a Paryżem może doprowadzić do sytuacji, gdy Marokańczycy będą poszukiwać nowych źródeł finansowania i tę lukę może wypełnić ZSRR ${ }^{62}$. W listopadzie 1958 r. podczas dyskusji w Pentagonie wojskowi i politycy uznali, iż amerykańska pozycja w Maroku została osłabiona w wyniku „radzieckiej presji”, która była efektem nawiązania stosunków dyplomatycznych i wysłania dużej misji ${ }^{63}$.

Nie należy wątpić w prozachodnie sympatie króla, który z jednej strony uważał, że radziecka obecność na Morzu Śródziemnym jest dużym problemem, z drugiej jednak - miał nadzieję na pewne korzyści polityczne (wzmocnienie pozycji Rabatu w ruchu państw niezaangażowanych oraz argumenty do zwalczania głosów krytykujących zbyt ścisłą współpracę z Waszyngtonem, wspierającym Izrael), ekonomiczne (źródło kapitału do rozwoju gospodarczego, rynki zbytu dla marokańskich towarów, zwłaszcza cytrusów i fosforanów) oraz wojskowe (dostęp do broni z Europy Wschodniej, przeciwwaga dla zbrojeń Algierii) ${ }^{64}$. Dlatego przed przygotowywaną w połowie lat 60. wizytą króla Hassana II w Moskwie w Waszyngtonie dość gorączkowo dyskutowano nad działaniami, które należałoby podjąć, aby zniechęcić króla do starań o części zapasowe do MiG-ów. Zdecydowano się ostatecznie wspierać rozwój marokańskich sił powietrznych (z uwzględnieniem marokańskich zdolności do ich utrzymania i obsługi, aby nie zachwiało to zbytnio budżetem) oraz zaproponować dostarczenie sprzętu dla sił lądowych, chociaż Rabat od lat zaopatrywał się u innych dostawców ${ }^{65}$.

Po wizycie w Maroku Podgornego w 1969 r. amerykańska ambasada w Rabacie wyraziła zaniepokojenie „sukcesami” ZSRR: otwarciem konsulatu generalnego w Casablance, utworzeniem w stolicy Centrum Kultury, wizytą radzieckich okrętów wojennych w Casablance, wizytą Podgornego, otwarciem połączenia Rabat-Hawana, obsługiwanego przez Aerofłot. Wyrażono „sugestię", że planowany w krótkim odstępie czasu od wizyty Podogornego wyjazd do Moskwy misji wojskowej z gen. Drissem na czele mógłby wywołać „błędne, a niekorzystne wrażenie, że Maroko ma niewiele szacunku dla wrażliwości USA i amerykańskiej opinii publicznej" ${ }^{66}$.

\footnotetext{
${ }^{62}$ National Intelligence Estimate, Washington, January 29, 1957, FRUS, 1955-1957..., s. 559.

${ }^{63}$ Memorandum on the Substance of Discussion at the Department of State-Joint Chiefs of Staff Meeting, Pentagon, Washington, November 21, 1958, FRUS, 1958-1960..., s. 772.

${ }^{64}$ Airgram A-34 from the Embassy in Morocco to the Department of State, February 17, 1969, FRUS, 1969-1976, Vol. E-5..., http://2001-2009.state.gov/documents/organization/92470.pdf [dostęp 7.12.2014].

${ }^{65}$ Action Memorandum from the Assistant Secretary of State for African Affairs (Williams) to Secretary of State Rusk, Washington, January 15, 1965, FRUS, 1964-1968..., s. 1963-1965.

${ }^{66}$ Telegram 2481 from the Embassy in Morocco to the Department of State, May 18, 1969, FRUS, 1969-1976, Vol. E-5..., http://history.state.gov/historicaldocuments/frus1969-76ve05p2/d98 [dostęp 12.12.2014].
} 
Jak pokazała przyszłość, obawy te okazały się płonne, co wkrótce skonstatowali sami Amerykanie. Współpracę Rabatu z Moskwą zaczęto postrzegać jako marokański pragmatyzm, nieumniejszający przyjaznych stosunków z Zachodem, w szczególności z USA ${ }^{67}$. Niepokój był tym mniejszy, że interesy USA w Maroku uznano za ważne, ale nie kluczowe dla bezpieczeństwa państwa ${ }^{68}$.

Ambasador Neumann, oceniając rok 1974, stwierdził, że mimo dobrych stosunków radziecko-marokańskich, był to rok zbliżenia między Rabatem i Waszyngtonem. Według niego Hassan II uważał, iż amerykańska obecność wzmacnia „konserwatywne i odpowiedzialne” reżimy arabskie ${ }^{69}$.

Wydaje się, że Rabat próbował balansować między Moskwą i Waszyngtonem w myśl zasady: „I Panu Bogu świeca, i diabłu ogarek”. Współpraca z ZSRR miała równoważyć wpływy Zachodu i wzmocnić autorytet międzynarodowy Maroka; istotna była także w kontekście relacji marokańsko-algierskich. Z pewnością Moskwa nie była usatysfakcjonowana poziomem i efektami współpracy wojskowej, jednak jej sukcesem wydaje się samo pełnienie roli „straszaka” Waszyngtonu - jak wynika z dokumentów, Amerykanie niejednokrotnie uwzględniali postulaty Rabatu w obawie przed zwróceniem się do Moskwy. Jednak wraz z rosnącym kryzysem w ZSRR radzieckie zaangażowanie w Maroku stawało się coraz mniejsze.

${ }^{67}$ National Intelligence Estimate 61-72, Washington, June 15, 1972, FRUS, 1969-1976, Vol. E-5..., http://history.state.gov/historicaldocuments/frus1969-76ve05p2/d125 [dostęp 14.12.2014].

${ }^{68}$ Analytical Summary, Washington, November 28, 1972, FRUS, 1969-1976, Vol. E-5..., http:// history.state.gov/historicaldocuments/frus1969-76ve05p2/d134 [dostęp 12.12.2014].

${ }^{69}$ End of the Year Assessment of Morocco and U.S.-Moroccan Relations from Ambassador, 17.01.1975, http://wlstorage.net/oc/2476/16090.pdf [dostęp 12.12.2014]. 